Згідно з оцінками Організації Об’єднаних Націй розмір легалізованого в світовому масштабі доходу кримінального походження упродовж останніх років становило від 2 до 5\% світового внутрішнього
валового продукту щороку, або в грошовому еквіваленті від 800 млрд. дол. США до 2 трлн. дол. США. 3 валового продукту щороку, або в грошовому еквіваленті від 800 млрд. дол. США до 2 трлн. дол. США. 3
них, за даними Світового банку приблизно 1-1,6 трлн. дол. США трансформуються в іноземні юрисдикції, них, за даними Світового банку приблизно 1-1,6 трлн. дол. США трансформуються в іноземні юрисдикції,
що $є$ офшорними зонами і великими фінансовими центрами, з метою їх приховування, кримінального вищо € офшорними зонами і великими фінансовими центрами, з метою іх пр
користання, а також подальшого введення в легальний економічний обіг.

\section{Руслана Крамар}

кандидат юридичних наук, доцент, декан юридичного факультету Львівського універ-

ситету бізнесу та права

ORCID:/https://orcid.org/0000-0001-5086-9845

\section{ДЕЯКІ АСПЕКТИ МІЖНАРОДНОГО МЕХАНІЗМУ ВИЯВЛЕННЯ, РОЗШУКУ, АРЕШТУ ТА КОНФІСКАЦІЇ АКТИВІВ, ЛЕГАЛІЗОВАНИХ ЗЛОЧИННИМ ШЛЯХОМ}

У статті проведено аналіз міжнародного механізму в частині забезпечення прочедур виявлення, розшуку, арешту злочинних активів, а також управління конфіскованим майном апробованого в зарубіжних дер жавах. Встановлено, що міжннародний механізм протидіі відмиванню коштів складається з ряду елементі що мають відномення до відстежження активів, наприклад, заходи належної перевірки клієнта фінансовим установами та нефінансові комериійні структури.

На основі проведеного дослідження зарубіжного законодавства і правозастосовної практики з питань заморожуввання, арешту та конфіскаиії злочинних активів, а також управління конфіскованими активами

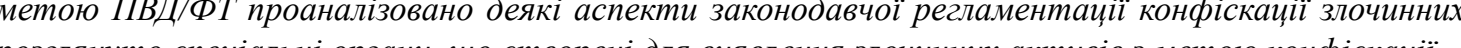

Ключові слова: злочині активи, розслідування, кондіскачія, мізниродний правовий механізм, коруп иійні злочини.

Крамар $P$.

Некоторые аспекты межсународного механизма выявления, розыска, ареста и конфискации активов, легализованных преступным путем

В статье проведен анализ международного механизма в части обеспечения процедур выявления розыска, ареста преступных активов, а также управление конфискованным имуществом апробированно20 в зарубежных государствах. Установлено, что международный механизм противодействия отмывани о средств состоит из ряда элементов, имеющих отномение к отслеживанию активов, например, меры по надлежащей проверке клиентов финансовыми учреждениями и нефинансовые коммерческие структуры.

На основе проведенного исследования зарубежнного законодательства и правоприменительной практики по вопросам замораживали, ареста и конфискации преступных активов, а также управлени конфискованными активами с целью ПОД / ФТ проанализированы некоторые аспекты законодательной ре гламентаиии конфискации преступных активов и рассмотрены специальные органы, созданные для выявления преступных активов с целью конфискачии.

Ключевые слова: преступные активы, расследование, конфискация, международный правовой меха низм, коррупчионные преступления.

Kramar $\boldsymbol{R}$.

Some aspects of the international mechanism for identifying, searching, seizing and confiscating criminally legalized asset

The article analyzes the international mechanism in terms of ensuring the procedures for detection, search, seizure of criminal assets, as well as the management of confiscated property of the tested in foreign countries. It has been established that the international anti-money laundering mechanism consists of a number of elements related to asset tracking, such as due diligence by financial institutions and non-financial commercial entities.

Based on a study of foreign legislation and law enforcement practices on the freezing, seizure and confiscation of criminal assets, as well as the management of confiscated assets for AML/CFT, some aspects of the legal regulation of confiscation of criminal assets are analyzed and special bodies set up to identify criminal assets confiscation.

Keywords: criminal assets, investigation, confiscation, international legal mechanism, corruption crimes.

Постановка проблеми. На рубежі тисячоліть проблема забезпечення глобальної безпеки $є$ предметом широкого спектру науково-практичних досліджень у форматі стратегічної діяльності міжнародних організацій та інституцій.

О Руслана Крамар, 2021
Більша частина активів, легалізованих за допомогою здійснення корупційних злочинів, ніколи не буде повернута потерпілими країнами 3 причини неможливості визначити їх місцезнаходження. На сьогодні міста, де здійснюються великі фінансові операції і масова торгівля фінансовими продуктами включають в себе не тільки традиційні центри, такі як Нью-Йорк, Лондон і Токіо, а й зростає число нових фінансових столиць в Азії, на Близькому Сході і за їх межами. Отриманий прибуток в результаті вчинення злочинів, часто перекладається в фінансові центри в спробі перешкодити зусиллям правоохоронних органів, спрямованим на виявлення та відстеження активів, легалізованих злочинним шляхом. Тому, ефект від розслідування злочинів, пов'язаних з корупцією в державних органах, відмиванням коштів, а також фінансових злочинів багато в чому залежить від здатності слідчого відстежити злочинну схему, що дозволить виявити кінцевого бенефіціара грошових коштів.

Аналіз наукових досліджень та публікацій. Значний внесок у розробку питань здійснення фінансового контролю, протидії відмиванню злочинних доходів, в тому числі за кордоном і міжнародного співробітництва держав 3 метою їх конфіскації внесли такі дослідники як: Г. Буяджи, О. Бусол, Л. Гарбовський, М. Ліхачов, О. Рєзнікова, Г. Терещук та ін.

Серед наукових праць представників зарубіжної правової науки у даній сфері доцільно відзначити таких авторів як: Рене Брюларт (René Brülhart), Роберт Харрісон (Robert A.Harrison), Джи Вон Пак (Ji Won Park), Марк Піт (Mark Pirth), Джей Шарман (J.C. Sharman).

Метою дослідження $\mathbf{\epsilon}$ аналіз міжнародних механізмів виявлення, розшуку, арешту та конфіскаші активів, легалізованих злочинним шляхом з метою покращення національної практики у даній сфері.

Виклад основного матеріалу дослідження. Міжнародний механізм протидії відмиванню коштів складасться з ряду елементів, що мають відношення до відстеження активів, наприклад, заходи належно перевірки клієнта фінансовими установами та нефінансові комерційні структури і особи певних професій. Кожен 3 цих елементів, в повній мірі охоплений в цій публікації, повинен бути належним чином врахований 3 тим, щоб виявити потенціал ї використання слідчими при відстеженні викрадених активів [1].

Міжнародне співробітництво охоплює три аспекти, шо мають вілношення до шього дослідження, а саме:

взаємна правова допомога;

репатріація доходів здобутих злочинним шляхом / корупціт,

екстрадиція.

Кожен 3 цих аспектів супроводжується наступними проблемами:

банківська таємниця;

вимога деяких країн щодо взаємного визнання відповідного діяння злочином;

- повільні темпи обміну інформацією між країнами, зокрема через відмінності в процесуальних системах між країнами.

Конвенція ООН щодо протидії корупції виступає в основі механізму, що покращуєе ефективність боротьби з корупцією та відмиванням грошових коштів в цій сфері.

Міжнародне законодавство щодо регулювання взаємної правової допомоги у разі відсутності двосторонніх договорів забезпечує розробку країнами механізмів для здійснення міжнародного співробітництва. Йдеться про запобігання використанню банківської таємниці для перешкоджання надання взаємно правової допомоги (рекомендація №.40 групи розробки фінансових заходів боротьби з відмиванням грошей (FATF) та прискорення обробки звернень про надання взаємної правової допомоги)) [1].

Незважаючи на те, що інституція з виявлення, розшуку та управління корупційними та іншими активами в Україні створена не так давно, в Європі та світі вже давно існують офіси із повернення та управління активами. В Європейській поліцейській асоціації зазначають, що в останні роки країни-члени $С$ С та європейські інститушії зосередили свої зусилля на протидії та запобіганні злочинній діяльності, стягнення конфіскованих активів постас одним із найважливіших та дісвих заходів протидії корупнії. Статтею 31 Конвенції ООН щодо протидії корупції, ратифікованою Законом України № 251-V від 18. 10. 2006 р. зазна- 
чено, що кожна держава-учасниця вживає, таких заходів, які можуть бути необхідними для забезпечення можливої конфіскації:

а) доходів від злочинів, що визначені цією Конвенцією, або майна, вартість якого відповідає вартості таких доходів;

б) майна, обладнання та інших засобів, які використовувались або призначалися для використання під час вчинення злочинів, шо визначені шією Конвенцією [2]

Окрім національних зусиль, Європейська Комісія через Директиву ЄС (2014/42 / ЄС) про заморожування та конфіскацію доходів від злочину, встановлює важливі стандарти для стягнення злочинного прибутку. Зазначимо, що велика кількість держав-членів вже сформували профільні органи з виявленн та управління арештованими активами. Проте, є деякі країни, у яких така діяльність не проводиться на центральному рівні, що вносить суттеву складність в загальноєвропейську місію боротьби із корупцією. Оскільки на європейському рівні контроль за ефективністю систем управління активами, що здійснюєтьея на центральному рівні неможливий без участі держав-членів, створення офісів з виявлення, розшуку та управління арештованими активами $є$ невід'ємним інструментом міжнародного антикорупційного співробітництва [3]. Для членів Свропейського Союзу розшук, арешт та повернення корупційних активів $\epsilon$ прерогативними напрямками протидії корупції. У деяких державах-членах $Є С$ управління та розпоряджання активами регулюється законом або підзаконним процесуальним законодавством. При цьому, норми законодавства можуть мати як кримінальну, так і адміністративному природу. У Бельгії, Болгарії, Кіпрі, Франції, Греції, Угорщині, Ірландії, Нідерландах, Польщі, Португалії, Румунії, Словаччині, Словенії, Іспанії, Швеціи управління кримінальними активами регулюється різними правовими актами за юридичною силою, деяк 3 яких можуть включати кримінально-процесуальні дії, які доповнюють один одного $з$ цього питання [5].

На основі проведеного дослідження зарубіжного законодавства і правозастосовної практики 3 питань заморожування, арешту та конфіскації злочинних активів, а також управління конфіскованими активами з метою ПВД/ФТ відобразимо деякі аспекти законодавчої регламенташії конфіскашії в контексс зарубіжного досвіду (табл.1).

Таблиия 1

Окремі аспекти законодавчої регламентації конфіскації в зарубіжних державах* Законодавча регламентація конфіскації в зарубіжних державах зпочинним шляхом, а також з менеджментом конфіскованих доходів в зарубіжних країнах ре- $\mid$ Великобританія, Ірландія гламентовані на законодавчому рівні.

В державах з федеральним устроєм кожен із суб'єкттів федерації, крім федерального, має власне законодавство, спрямоване на боротьбу з відмиванням злочинних доходів, і застосовуе пра- США, Австралія, Канада вила про громадянську конфіскацій без засудження особи в кримінальному порядку. Закони про громадянську конфіскацію мають зворотну силу, оскільки такі доходи ніколи не змжуњ стапи закон ої діяльност.

У ряді країн норми про цивільну конфіскацію відображені в кримінальному кодексі.

*Складено автором самостійно.

Розглянемо більш детальніше спеціальні органи, що створені для виявлення злочинних активів метою громадянської конфіскації (табл. 2)

Таблиия 2

Спешіальні органи, створені для виявлення злочинних активів з метою громадянської конфіскації \begin{tabular}{|l|l|}
\hline Країна & Назва органу \\
\hline
\end{tabular} Основні цілі та завдання виявлення злочинно

активів ідентифікація активів, отриманих або імовірно отриманих прямо або побічно Criminal Assets Bureau -CAB), злочинної поведінки; прийняття відповідних заходів, спрямованих на вилучення таких активів або управління ними, а також проведення будь-яких необхідних

британія Authority - FCA),
діяльності, і боротьбі з анонімними міжбанківськими платежами

Окремого спеціального органу

ської канадської кінної поліші

аглляд у сфері здійснення заморожування активів і застосування фінансових

Канада до протидії відмиванню до- отриманих в результаті злочинної діяльності.

ним шляхом (RCMP Proceed of crime Program)

. фінансове розслідування здій-зборі інформачії про розмориі конфіскаціі майна, що має незаконне походження.

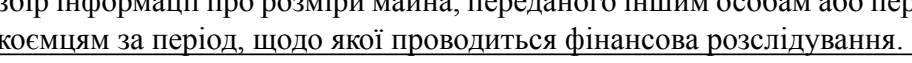

Складено автором самостійно.

Ірландія стала однією з перших країн, що заснували для конфіскації активів спеціальний орган Бюро кримінальних активів (Criminal Assets Bureau - CAB), яке ініціює цивільний процес конфіскації. У штаті бюро 70 співробітників, в тому числі представники поліції, податкової інспекції, державні службовці 3 Департаменту соціального захисту населення та Міністерства юстиції. За ірландським законом, прибуток, отриманий від злочинноі діяльності, може обкладатися податком і Бюро (його податкове управління) має широкі повноваження 3 проведення розслідувань і пошуку, а також стягування таких податків. Діяльність Бюро повністю фінансується з державної скарбниці, перед ним не ставляться будь-які фінансов показники, а всі повернуті кошти передаються казначейству [6].

У Великобританії органи, призначені для виявлення злочинних активів, в даний час знаходяться в стані трансформації. 32002 p. такими повноваженнями був наділений Агентство по поверненню активі (Assets Recovery Agency - ARA), яке в 2007 p. було об’єднано з Агентством з організованої злочинност (Serious Organised Crime Agency - SOCA), перетворене в Національне агентство з боротьби зі злочинами (National Crime Agency - NCA).

32013 р. в Великобританії почало функціонувати Агентство з фінансової діяльності (Financial Conduct Authority - FCA), яке наділене повноваженнями з розслідування фінансових злочинів [6]. Передбачасться, що в своїй діяльності Агентство з фінансової діяльності співпрацюватиме з різними право-

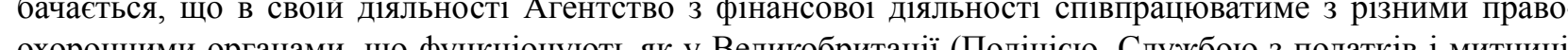
охорон .

У Канаді немає спеціального органу, наділеного повноваженнями щодо виявлення злочинних активів $з$ метою подальшої їх конфіскації в цивільному порядку. Допомогу поліції у виявленні незаконних
доходів надає група судових бухгалтерів, які аналізують ознаки «відмиванну, що діс в складі Міністерства доходів надає група судових бухгалтерів, які аналізують ознаки «відмивання», що діє в складі Міністерства громадських робіт і державних послуг. Їх звіти служать доказами в суді. Територіально судові бухгалтери знаходяться в будівлях поліції, але ій не підпорядковуються. В процесі розслідування можуть створюватися робочі групи, куди крім судових бухгалтерів входять і прокурори.

У континентальних країнах, наприклад в Словенії, фінансове розслідування здійснюється Спеціальною прокуратурою в межах її компетенції. В ході фінансового розслідування щодо активів, що мают незаконне походження, застосовуються положення кримінально-процесуального законодавства. Відносно конфіскації майна, що має незаконне походження, застосовуються положення цивільного процесуального законодавства, якщо в законі не передбачено інше. Прокурор дає розпорядження про проведення фінансового розслідування при дотриманні наступних умов:

якщо буде встановлено, що є підстави для підозр щодо вчинення підозрюваним, обвинуваченим чи померлою особою діяння, згаданого в законодавстві; 
- якщо поліція звернулася з мотивованою скаргою щодо наявних підозр щодо того, що незаконне майно може бути передано правонаступнику або особі, яка має тісний зв'язок з власником, або було змімайно може бути передано правон].

Щодо вітчизняної практики міжнародного співробітництва, то відповідно до статті 9 Закону Украіни «Про Національне агентство України з питань виявлення, розшуку та управління активами, одержаними від корупційних та інших злочинів» до основних функцій АРМА віднесено, серед іншого, здійснення співробітництва з органами іноземних держав, до компетенції яких належать питання щодо виявлення, розшуку та управління активами, іншими компетентними органами іноземних держав, відповідними міжнародними організаціями [8]

Пунктом 3 частини першої статті 16 Закону закріплено, що АРМА забезпечує співробітництво 3 міжнародними, міжурядовими організаціями, мережами, діяльність яких спрямована на забезпечення міжнародного співробітництва у сфері виявлення, розшуку та управління активами, у тому числі з Камденською міжвідомчою мережею з питань повернення активів (CARIN), та представляе Україну в цій організації [7].

Таким чином, АРМА на рівні законодавства України уповноважене на забезпечення співробітництва 3 міжнародними, міжурядовими організаціями, мережами, діяльність яких спрямована на забезпечення міжнародного співробітництва у сфері виявлення, розшуку та управління активами, а також з аналогічними агентствами країн світу

АРМА використовуються міжнародні майданчики для інформування міжнародних партнерів щодо досягнень України у сфері виявлення і розшуку злочинних активів, управління арештованим і конфіскованим майном, особливостей функціонування національної системи повернення активів, як складово системи протидії корупції [8].

В рамках міжнародної діяльності АРМА здійснюються заходи з аналізу прогалин в міжнародних актах, сучасних викликів та тенденцій в сфері розшуку злочинних активів та управління арештованим майном, досліджень, аналітичних наукових праць міжнародних інституцій та експертів, коментарів та пропозишій, які порушуються іноземними партнерами на міжнаролних платформах, i за результатами такого аналізу розроб аналізу роз і ним майном, повернення злочинних активів з іноземних юрисдикцій в Україну [8].

Подальше вивчення і застосування у вітчизняну практику міжнародних механізмів виявлення та відстеження активів, легалізованих злочинним шляхом та підвищення ефективності роботи агентств щодо розшуку та повернення активів $\epsilon$ пріоритетним та невідкладним в забезпеченні національних інтересів.

Висновки. Таким чином, для вирішення проблем в реалізації механізму в частині забезпечення процедур заморожування, арешту і конфіскації злочинних акиивів, управлння конфіскованим майном $з$ метою ПВД / ФТ, для України представляють інтерес наступні правові конструкції, апробовані в правозастосовній діяльності зарубіжних держав:

1. Законодавча та судова практика показує, що, захищаючи фінансові інтереси, в тому числі зовнішньоекономічні, держава може переглянути питання про перенесення тягаря доведення і застосувати зворотне доведення за окремими категоріями справ. Дане положення застосовується в умовах будь-яко держави, $є$ складовою кримінальної політики, сформованої під впливом сучасних міжнародних стандартів в сфері боротьби з організованою злочинністю.

2. В більшості зарубіжних країн використовується більш конкретизований підхід, при якому в законах докладно перераховуються види майна, вигода, блага, отримані в зв'язку зі здійсненням злочинної (в тому числі предикатної) діяльності.

Міжнародні експерти в сфері конфіскації злочинних активів вказують стосовно конфіскації поза кримінального провадження, що для ефективної роботи щодо конфіскації активів необхідно, щоб співробітники правоохоронних органів пройшли спеціальну підготовку. У тих випадках, коли досвід державних структур в сфері цивільної конфіскації невеликий, слід розглянути можливість призначення особливих суддів і прокурорів. хоча введення спеціалізації веде до додаткових витрат, тільки така практика може стати ефективною, оскільки в разі перевантаженості судів іншими позовами, розгляд справи про конфіскашію може бути затягнутий на тривалий час, а спірне майно зникнути. Як правило, в прокуратурі країн, де прийнята громадянська конфіскація, $є$ спешіальні відділи, які займаються питаннями конфіскашії. Зарубіжний досвід показус, шо така схема прашос більш ефективно, ніж ознайомлення всіх співробітників пропуратури $з$ цією специфічною галуззю права.

\section{Списко використаних джерел}

1. Отслеживание похищенных активов: справочник практикующего специалиста. Международный центр по возвращению активов. 2010. URL: https://Users/Admin/Desktop/\%D0\%90\%D0\%A0\%D0\%9C $\% \mathrm{D} 0 \% 90 /$ Tracing\%20Stolen\%20Assets\%20. (дата звернення: 08.02.2021).

2. Конвенція Організації Об’єднаних Націй проти корупції від 31.10.2003. Верховна Рада України. URL: https://zakon.rada.gov.ua/go/995_c16 (дата звернення: 02.02.2021)

3. Criminal asset recovery in the EU: Europol Criminal Assets Bureau, Financial Intelligence European Police Office (Europol). 2016. URL: https://www.europol.europa.eu/sites/default/files/documents/criminal_asse _recovery_in_the_eu_web_version_0.pdf (дата звернення: 08.02.2021).

4. Бусол О. Виявлення, розшук та управління активами, одержаними від корупційних та інших злочинів: міжнародно-правові аспекти і досвід для України. Центр досліджень соиіальних комунікаиій НБУв. 2020. URL: http://nbuviap.gov.ua/index.php?option=com_content\&view=article\&id=2374:viyavlennyarozshuk-ta-upravlinnya-aktivami-oderzhanimi-vid-koruptsijnikh-ta-inshikh-zlochiniv\&catid=8\&Itemid=350 (дата звернення: 08.02.2021)

5. Давидюк А. М. Правове забезпечення публічного адміністрування у сфері виявлення, розшуку та управління активами, одержаними від корупційних та інших злочинів: дис. ... канд. юр. наук: 12.00 .07 Київ, Україна. 2020. 204c.

6. Перспективи застосування механізмів заморожування, арешту і конфіскації злочинних активів, механізмів управління конфісковані активи (порівняно-правове дослідження). Міжннародний навчально-методичний центр фінансового моніторингу. 2014. 520 c. URL: https:// https://www.twirpx.com/ ні-металочний центр фінансового монім

7. Повернення активів та управління конфіскованими: 09.10.2020. https://www.ukrinform.ua/rubriceconomy/3115142-povernenna-aktiviv-ta-upravlinna-konfiskovanimi-kabmin-zatverdiv-plan-zahodiv.html есоnomy/3115142-povernenn

8. Закон України «Про Національне агентство України з питань виявлення, розшуку та управління активами, одержаними від корупційних та інших злочинів» від 10 листопада 2015 року №772-VIII. Bidoмості Верховної Ради (BBP). 2016. № 1. Ст. 2 .

9. Агентство з розшуку та менеджменту активів: офіційний сайт URL:https://arma.gov.ua/carin (дата звернення: 06.02.2021).

\section{References}

1. Otslezhivanie pohishchennyh aktivov: spravochnik praktikuyushchego specialista. [Tracking Stolen Assets: A Practitioner's Guide]. (2010). Mezhdunarodnyj centr po vozvrashcheniyu aktivov. Retrieved from https:// Users/Admin/Desktop/\%D0\%90\%D0\%A0\%D0\%9C\%D0\%90/Tracing\%20Stolen\%20Assets\%20 Russian].

2. Konventsiia Orhanizatsii Obiednanykh Natsii proty koruptsii. (2003). [United Nations Convention agains Corruption]. Verkhovna Rada Ukrainy. Retrieved from https://zakon.rada.gov.ua/go/995_c16 [in Ukrainian]

3. Criminal asset recovery in the EU: Europol Criminal Assets Bureau, Financial Intelligence European Police Office (Europol). (2016). Retrieved from https://www.europol.europa.eu/sites/default/files/documents criminal_asset_recovery_in_the_eu_web_version_0.pdf [in English].

4. Busol, O. (2020). Vyiavlennia, rozshuk ta upravlinnia aktyvamy, oderzhanymy vid koruptsinnkh ta inshykh zlochyniv: mizhnarodno-pravov aspekty i dosvid dlia Ukrainy [Detection, search and management of assets derived from corruption and other crimes: international legal aspects and experience for Ukraine]. Tsentr doslidzhen sotsialnykh komunikatsii of NBUV - NBUV Center for Social Communications Research. Retrieved from http://nbuviap.gov.ua/index.php?option=com_content\&view=article\&id =2374:viyavlennyarozshuk-ta-upravlinnya-aktivami-oderzhanimi-vid-koruptsijnikh-ta-inshikh-zlochiniv\&catid [in Ukrainian].

5. Davydiuk, A. (2020). Pravove zabezpechennia publichnoho administruvannia u sferi vyiavlennia, rozshuku ta upravlinnia aktyvamy, oderzhanymy vid koruptsiinykh ta inshykh zlochyniv [Legal support of public administration in the field of detection, search and management of assets obtained from corruption and other crimes]: Candidate's thesis. Kyiv, Ukraina. [in Ukrainian].

6. Perspektyvy zastosuvannia mekhanizmiv zamorozhuvannia, areshtu $i$ konfiskatsii zlochynnykh aktyviv, mekhanizmiv upravlinnia konfiskovani aktyvy (porivniano-pravove doslidzhennia) [Prospects for the application of mechanisms for freezing, arrest and confiscation of criminal assets, management mechanisms

ISSN 2524-0129 (Print)/ ISSN (2664-5718) (Online). Актүальні проблеми правознавства. 1(25)/2021 
for confiscated assets (comparative legal study)]. (2014). Mizhnarodnyi navchalno-metodychnyi tsent finansovoho monitorynhu. Retrieved from https:// https://www.twirpx.com/file/1727064 [in Ukrainian].

7. Povernennia aktyviv ta upravlinnia konfiskovanymy: Kabmin zatverdyv plan zakhodiv [Return of assets and management of confiscated: The Cabinet of Ministers approved the action plan]. 09.10.2020. Retrieved from https://www.ukrinform.ua/rubric-economy/3115142-povernenna-aktiviv-ta-upravlinna-konfiskovanimikabmin-zatverdiv-plan-zahodiv.html [in Ukrainian].

8. Zakon Ukrainy «Pro Natsionalne ahentstvo Ukrainy z pytan vyiavlennia, rozshuku ta upravlinnia aktyvamy, oderzhanymy vid koruptsiinykh ta inshykh zlochyniv» [Law of Ukraine «On the National Agency of Ukraine for Detection, Investigation and Management of Assets Obtained from Corruption and Other Crimes»] vid 10 lystopada 2015 roku № 772-VIII. (2016). Vidomosti Verkhovnoi Rady-Bulletin of Verkhovna Rada of Ukraine, 1, 2 [in Ukrainian].

9. Ahentstvo z rozshuku ta menedzhmentu aktyviv: ofitsiinyi sait [Asset Search and Management Agency: official website]. Retrieved from https://arma.gov.ua/carin. [in Ukrainian].

Стаття надійшла до редакції 19.02.2021
Порядок публікаціі матеріалів

\section{у фаховому збірнику наукових праць}

1) Приймаються роботи, написані украйнською, російською або англійською

мовами, обсягом до 12 аркушів включно.

2) Рукопис статті повинен мати такі елементи:

-УДК;

-код ORCID;

- назва секції;

- прізвище та ініціали автора, науковий ступінь, посада;

- назва статті українською мовою;

- анотації українською і російською мовами (мінімум 700 знаків 3 пробілами), розширена аноташія англійською мовою (мінімум 1800 знаків з пробілами), які повинні містити короткий виклад актуальності, мету та результати дослідження;

- КАючові слова (не менше 5 позицій);

- основний текст статті;

- список використаних джерем;

-списов використаних джерел англійською мовою (References).

3) Окрім рукопису статті до редакції подається реферат (розширена анотація) ангіийською мовою (реферат має обов’язково містити: назву статті, прізвище та ініціали автора, посаду, місце роботи, короткий зміст статті. Мінімальний обсяг реферату - 300 сиів)

4) Стаття повинні містити такі емементи:

-постановку проблеми у загальному вигляді та ії зв'язок із важливими науковими чи практичними завданнями;

- аналіз останніх досліджень і публікацій, в яких започатковано вирішення цієї проблеми і на які спирається автор, виділення невирішених раніше частин загальної проблеми, котрим присвячується стаття;

- мету статті;

- виклад основного матеріалу дослідження з повним обгрунтуванням отриманих наукових результатів;

- висновки дослідження і перспективи подальших розвідок у даному напрямі.

Зазначені елементи виділяються в рукописі напівжирним шрифтом.

5) Стаття має бути набрана в текстовому редакторі Microsoft Word. Поля з усіх сторін

-20 мм. Шрифт - Times New Roman 14 з інтервалом 1,5 .

Посилання на використані джерела здійснюється безпосередньо в тексті. У

квадратних дужках зазначається порядковий номер використаного джерела, а через

кому - конкретна сторінка (приклад - [1, с, 15]).

6) До редакції на електронну адресу zbirnykapp@wunu.edu.ua подаються:

-екекронний варіант статті;

розширена анотація англійською мовою (реферат);

- завірена рецензія доктора або кандидата наук відповідного профілю (крім випадків, коли автор сам має науковий ступінь)

-довідка про автора на окремій сторінці (прізвище, ім'я, по-батькові повністю,

організація, посада, адреса, науковий ступінь, вчене звання, контактні темефони, поштова адреса для направлення авторського примірника журналу, електронна адреса),

7) Редакція очікує, що надані матеріали раніше не публікувалися і не передавалися для публікації до інших видань.

Статті, які не відповідають наведеним вимогам, не приймаються до розгляду. Рукописи проходять рецензування та перевірку на наявність плагіату, за результа тами якого редакиійна колегія приймае рішення про публікаиію статей або необхід ності їх доопраиювання авторами. 